\title{
CitaÇÃO, ALUSÃO, REFERÊNCIA: PROCEDIMENTOS INTERTEXTUAIS NO POEMA “NóS OS VENCIDOS DO CATOLICISMO”, DE RuY BELO
}

\author{
Adriano Tarra Betassa Tovani CARDEAL* \\ Maria Lúcia OUteiro FERNANDES
}

\section{Resumo}

Ruy de Moura Ribeiro Belo (1933-1978), relevante autor da literatura portuguesa contemporânea, produziu dezenas de poemas líricos relacionados, em diferentes graus, à temática judaico-cristã, tendo tomado a Bíblia sagrada como fonte primária de procedimentos intertextuais utilizados por ele. Focalizamos seu livro Homem de palavra[s] (1970), no qual o poema "Nós os vencidos do catolicismo" mostra algumas técnicas de intertextualidade mais usadas por Ruy Belo ao longo da sua obra lírica: citação, alusão e referência. Para um conhecimento e análise delas naquele texto poético, recorreremos às definições provindas dos críticos literários franceses Julia Kristeva (1941-), Gérard Genette (1930-2018) e Tiphaine Samoyault (1968-).

PalaVras-Chave: Ruy Belo. Nós os vencidos do catolicismo. Intertextualidade.

\section{INTRODUÇÃO}

Nos Estudos de Literatura Portuguesa Contemporânea, Ruy de Moura Ribeiro Belo (1933-1978) é considerado um dos mais notáveis

Mestrando de Literatura Portuguesa no Programa de Pós-Graduação em Estudos Literários da Faculdade de Ciências e Letras da Universidade Estadual Paulista/UNESP, Araraquara, São Paulo, Brasil. Bolsista da Coordenação de Aperfeiçoamento de Pessoal de Nível Superior (CAPES).

E-mail: cardealis.unesp@gmail.com Orcid iD: https://orcid.org/0000-0001-7940-9842.

** Professora Associada do Programa de Pós-Graduação em Estudos Literários e do Departamento de Linguística, Literatura e Letras Clássicas da Faculdade de Ciências e Letras da Universidade Estadual Paulista/UNESP, Araraquara, São Paulo, Brasil.

E-mail: outeiro.fernandes@unesp.br Orcid iD: https://orcid.org/0000-0001-5786-1440. 
poetas pós-1960. Na sua poesia, há uma perceptível inclinação por entender certas peculiaridades do tempo no qual viveu sucintos 45 anos, característica observada, por exemplo, na produção de textos poéticos ligados ao âmbito religioso. Nesse aspecto em especial, a poesia beliana fez crescer a relevância da cultura lusitana também quanto ao Catolicismo - decerto influenciado pelo quase decênio (1951-1961) em que fora membro interno do Opus Dei ${ }^{1}$.

Num estudo em que tenta explanar as relações entre o gênero lírico e a religiosidade, a germanista, crítica literária e filósofa Käte Hamburger (1896-1992) argumenta que “[...] o poema religioso não tem função em situação real, mas é a expressão artística duma alma religiosa” (HAMBURGER, 1975, p. 173). De nossa parte, não ousamos tanto quando nos pomos a pensar na poética beliana, tampouco se Ruy Belo tinha “[...] uma alma religiosa”, graças à qual compôs dezenas de poemas afeitos àquilo que subjaz à essência do Judaico--Cristianismo. Não fazemos essa ligação de maneira tão hermética porque a ficção poética existe independentemente de um poeta confessar a sua (des)crença em alguma espécie de religião. Essa atitude, aliás, está conforme ao fato de não ser necessário sabermos detalhes vividos pelo escritor para, apenas depois, sermos capazes de entender o eu lírico esculpido numa poesia; diante disso, concordamos que o poema, em sendo mesmo "religioso", “[...] não tem função em situação real [...]”. E Ruy Belo nos prova isso em seu vasto poemário.

Quem queira estudar os poemas de Ruy Belo precisa lidar com dificuldades que nos conduzem para além das fronteiras teóricas dos

1 Apesar de esse nome, cuja literal tradução é “Obra de Deus”, estar em latim, não adotamos, aqui, a formal recomendação ortográfica segundo a qual palavras/expressões latinas tenham de ser digitadas em caracteres itálicos, pois, acerca do referido Opus Dei, trata-se duma denominação institucional - um sociotopônimo -e não dum sintagma comum; logo, aquela convenção de ortografia não se aplica a nomes de instituições. E caso haja interesse em saber-se, em pormenores, do funcionamento e das práticas adotados pelo controverso Opus Dei cf. FERREIRA, Dario F.; LAUAND, Jean; SILVA, Márcio F. da. Opus Dei: bastidores - história, análise, testemunhos. Campinas: Verus, 2005, 230 p. Os autores desse livro são ex-numerários internos, assim como Ruy Belo passara a sê-lo no ano 1961. 
Estudos Literários. No Brasil, já faz quase seis décadas ${ }^{2}$ que o método de comentário analítico ${ }^{3}$ tem sido um dos mais usados no meio dos pesquisadores de Literatura. Todavia, essa técnica de análise literária será muito mais eficaz se os estudiosos desse campo também conhecerem, minimamente, algum conteúdo poético-narrativo do compêndio mediante o qual se forjou o grande arcabouço cultural de Oriente e Ocidente: a Bíblia Sagrada. Daí ser imprescindível ler-se esse texto compósito, para a pesquisa literária das obras em verso e em prosa relacionadas à Bíblia culminar em uma interpretação textual que reconheça, na textura bíblica, um manancial do qual leitores profissionais ${ }^{4}$ não podem abrir mão caso queiram compreender, integralmente, os escritos que estejam perante a incontornável ${ }^{5}$ necessidade de serem classificados como "literatura

2 Estamos pensando, por exemplo, nas preleções do crítico literário brasileiro Antônio Cândido de Mello e Souza (1918-2017), quanto à Teoria Literária, na Universidade de São Paulo (USP), biênio 1963-1964, nas quais, de modo habitual, ele ensinava, aos seus discentes, métodos (surgidos na Alemanha e divulgados por grandes germanistas, como Emil Staiger [1908-1987] e Benno von Wiese [1903-1987]) por intermédio dos quais os estudantes de Letras podiam, eficazmente, analisar poemas das mais variadas naturezas.

3 Em $O$ estudo analítico do poema, de Antônio Cândido, vemos em detalhe essa metodologia da qual nos servimos para a leitura dos poemas de Ruy Belo. Cf. Referências.

4 Não só, mas principalmente os críticos literários, pois são estes quem ajudam os leitores não profissionais a melhor entender um texto após as necessárias explicações feitas a respeito dele.

5 Essa "incontornável necessidade" de pôr, sob a rubrica "literatura religiosa" ou "poesia religiosa”, poemas e narrativas nos quais a abordagem da religiosidade judaico-cristã se faz de maneira muito variada, desvela uma confusão terminológica, já que a própria variedade de que se compõe essa nomenclatura não facilita o procedimento analítico. É preciso, por isso, que o pesquisador de determinado texto que se possa incluir no grupo da chamada "poesia religiosa" apresente as nuanças que distingam, por exemplo, os poemas "Nós os vencidos do catolicismo" e "Vestigia Dei" (do livro Aquele grande rio Eufrates [1961]. Cf. Referências) ambos de Ruy Belo, ambos classificáveis como "poesia religiosa”, mas com grande diferença no tom com que se apresenta a mundividência do eu lírico: no primeiro poema - como neste artigo demonstraremos -, trata-se de uma voz poética desesperançada e que busca entre as criações humanas aquilo que Deus já não pode ofertar aos que nele criam; no segundo, vê-se um eu poético que se encanta com tudo quanto Deus criou e, assim, dirige-se ao Criador mediante reconhecimento de que tudo que há de bom na vida (das coisas mais triviais às mais esplendorosas) provém dele. É nisso que consiste a fatual importância de conceituar melhor o que venha a ser um "poema religioso". 
religiosa”, a exemplo do que se nota em muitos poemas de Ruy Belo e demais poetas que nos legaram uma poesia fundamentada na Sagrada Escritura.

Urge, portanto, praticar-se uma cultura bíblica mínima por quem queira fatualmente estudar a literatura religiosa, visto que, como defendia o crítico literário, filósofo e teólogo canadense Herman Northrop Frye (1912-1991), era necessário aceitar que “[...] o mito da Bíblia deveria servir de base à instrução literária: o mapeamento imaginativo da situação humana é tão amplo que tudo tem ali o seu lugar” (FRYE, 2017, p. 96). Demais, esclarece que “[...] 'mito', assim como 'fábula' e 'ficção', é um termo técnico de crítica literária; o sentido popular que veio a adquirir, de 'inverídico', considero degradação da linguagem” (p. 97). E essa opinião fryeniana merece, pelo menos, reconsideração à luz dos Estudos Literários no século XXI. Então, para contribuir um pouco nessa tarefa, aqui mostraremos o meio empregado por Ruy Belo para, havendo recorrido a citações, alusões e referências de passagens bíblicas em certos versos de "Nós os vencidos do catolicismo", ressignificar e moldar, nessoutra tessitura, a expressão de um eu lírico "desamparado" por Deus.

\section{“Poesia Religiosa”, UM CONCEITO ABRANGENTE}

No Ocidente, quando falamos de "literatura religiosa" (de maneira geral) ou "poesia religiosa” (de modo específico), estamos nos situando, necessariamente, num histórico de escritos poéticos que deitam suas raízes na tradição cristã iniciada pouco após a morte do último apóstolo de Jesus de Nazaré, João de Betsaida (9-c.103), autor do quarto evangelho e das três epístolas que levam o nome desse servo de Cristo, e o livro final, "Apocalipse". E é com base nessa percepção que o lusitanista português Gonçalo Vítor Plácido Cordeiro (1983-) afirmou: “[...] o problema da poesia religiosa em Ruy Belo é, como de resto estava persuadido o autor, assunto passível de suscitar controvérsias, dependendo dos termos em que é abordado. Também a comunidade de críticos se tem dividido" (CORDEIRO, 2011, p. 109). Esse é, portanto, o estado da 
questão referente ao que seja uma poesia religiosa e se esta é ou não uma denominação aplicável a certos poemas publicados por Ruy Belo.

Há palavras e expressões que usamos habitualmente e, por força do uso corriqueiro, nós as consideramos suficientemente claras/inequívocas; e o efeito mais imediato disso é que, não raro (exceto em contextos que exijam exatidão conceitual - como se dá em textos técnico-científicos, por exemplo), não nos preocupamos se uma palavra ou expressão está sendo tomada corretamente. No que interessa a este artigo, referimo-nos à ideia de "poesia religiosa", cujo emprego, na Literatura Portuguesa (faz, pelo menos, uns setecentos anos), ladeado por locuções supostamente sinonímicas entre si - "poesia sacra/sagrada", "poesia cristã", "poesia de devoção", "poesia de meditação", "poesia metafísica”, "teopoesia” etc. -, suscita bastante confusão devido ao ora alargamento, ora estreitamento semântico com que tem sido registrada em textos de crítica literária, parte dos quais explicitam a incerteza que circunda a aplicação dessa nomenclatura.

Augusto César Pires de Lima (1883-1959), filólogo português, esteve entre aqueles que pareciam não se incomodar com variações terminológicas para referir-se à "literatura religiosa”: “[...] se as nossas composições de caráter sacro ou devoto nem sempre revelam inspiração fácil, a verdade é que, em todas as épocas da nossa Literatura, uma ardente fé $^{6}$ religiosa produziu obras-primas nos gêneros épico, bucólico, lírico ou dramático" (LIMA, 1942, p. 6). Adiante, disse: "Sendo a Literatura a expressão da vida de um povo, os nossos escritores não podiam alhear-se do misticismo que envolvia os portugueses, desde o berço até a tumba [...]" (p. 7). E concluiu: “[...] a verdade insofismável é que, desde as cantigas de romaria, as bailias e barcarolas dos trovadores, até composições de caráter nacionalista dos contemporâneos, a exaltação mística aparece em todas as épocas a influir nos poetas de maior renome" (p. 8). Neste trecho de Lima, lemos quatro adjetivos ("sacro", “devoto", "religiosa”, “mística”) e um

6 De novo, eis a inadequada afirmação de que só mediante "[...] uma ardente fé religiosa [...]" seria possível a criação de “[...] obras-primas [...]” imbuídas de religiosidade e em quaisquer gêneros literários. 
substantivo ("misticismo"), os quais, no entendimento desse estudioso lusitano, são meros sinônimos e, por isso, facilmente intercambiáveis uns pelos outros, sem prejuízo de sentido. Entretanto, essa mistura semântica não contribui para um leitor não especialista em Literatura ver, com plena nitidez, quais são as características de uma poesia que, de modo impreciso, possa ser denominada "sacra", “devota”, "religiosa" e (ou) "mística” inequivocamente.

De forma parecida, quase nove decênios antes, o lusitano poeta, dramaturgo, crítico e historiador da literatura José Maria da Costa e Silva (1788-1854), numa homenagem ao padre e poeta quinhentista Baltasar Estaço (1570-16-), também traçou poucas linhas sobre o cultivo da poesia religiosa em terras lusíadas:

Não sei por que fatalidade poetas portugueses de todos os tempos têm mostrado a mais completa inaptidão para compor poemas sacros, ou devotos. Mesmo os que, como Camões ou Bocage, se haviam distinguido e alcançado o primeiro lugar no Parnaso, não fizeram cousa que passasse as raias da mediania.

O mesmo Frei Agostinho da Cruz, que tinha nascido superior em talento poético ao seu irmão Diogo Bernardes, e que, entre nós, deitou a barra mais longe em poesia de devoção, dirá alguém que entenda desta matéria que pode competir com o que alguns italianos têm escrito neste gênero? [...] (SILVA, 1854, p. 12-13).

Neste caso, é notável que Silva recorreu a dois adjetivos ("sacros" e "devotos") e a um substantivo ("devoção"), tendo-os tomado como simples sinônimos entre si, a fim de referir-se ao que, mais genericamente, costuma-se chamar de "poemas religiosos"; logo, ele esteve entre os lusitanistas que não se ocuparam de diferenciar aquelas designações.

Se lemos a avaliação feita pelo ensaísta, docente e crítico literário jerseiano Gustavo Rubim (1962-), em relação ao poema "Homem para deus"7, frustramo-nos, ainda, com tal problema de confusão conceitual

Nome do 4 poema da seção "Apresentação" do livro Aquele grande rio Eufrates, de Ruy Belo. 
na tentativa de escrever sobre um texto beliano. Mistura, pois, estes três adjetivos, tomados sinonimicamente: "místico", "religioso", "metafísico".

Ensaiemos, pois, reler um poema fácil de ler: poema que, logo à primeira, se mostra poema místico ou religioso ou, como se acusava há trinta anos, "metafísico". Quanto mais não seja, pela ocasião de ler poemas místicos ou religiosos que não deixam de ser poemas de pleno direito ou, ainda, pela esquisita raridade que é ler poemas abertamente religiosos oriundos de um país que há (sic) o hábito de se considerar profundamente religioso (RUBIM, 2003, p. 87).

Em outra avaliação feita pelo ensaísta e literato português José Régio $^{8}$ (1901-1969), junto do poeta Alberto de Serpa Esteves de Oliveira (1906-1992), sobre a poesia religiosa, vemos que eles são críticos cônscios de que não é adequado misturarem-se os nomes com os quais se vêm designando poemas baseados no âmbito religioso:

Raros na nossa poesia os poemas religiosos que atinjam superior nível metafísico, ou uma consciência profunda e analítica, ou a riqueza dos embates entre a fé e a tentação [...]; isso mesmo nos pôs perante um problema sobretudo instante para os poetas modernos: da concepção de vida religiosa que tivéssemos, ou de vida mística, dependeria a inclusão ou exclusão de certos poemas. Sabe-se como, nos tempos modernos, se tem alargado o significado do termo "misticismo". Preferimos, porém, limitar-nos aos poemas mais diretamente religiosos (RÉGIO; SERPA, 1958, p. 10-11).

Dessa maneira, se comparamos parte da poesia beliana a outros poemas portugueses que, sem dúvida, têm finalidade laudatória a uma divindade - a exemplo das Cantigas de Santa Maria, recolhidas pelo rei português Afonso X, o sábio (1221-1284) -, vemos que, conquanto se constate um teor religioso em muitos textos poéticos de Ruy Belo, estes não se dão no mesmo grau com que se compôs a maior parte da tessitura

$8 \quad$ Pseudônimo de José Maria dos Reis Pereira. 
poemática da tradição lusitana atinente à denominada "poesia religiosa”. Ainda assim, parece justo fazer que os escritos poéticos belianos embasados na fé judeu-cristã sejam elencados à longa linhagem da literatura religiosa, há séculos praticada em Portugal.

\section{INTERTEXTUALIDADE, TRANSTEXTUALIDADE}

Transcorridas algumas décadas, a palavra "intertextualidade", correlata ao conceito ideado pela psicanalista e crítica literária búlgarofrancesa Julia Kristeva (1941-), baseada no seu estudo quanto à obra do filósofo russo Mikhail Mikhailovich Bakhtin (1895-1975), mantevese dominante quando se discutia em que medida um texto poderia relacionar-se com outro(s), postura teórica da qual houve derivações mais agudas e variantes, conforme formulação do crítico literário francês Gérard Genette (1930-2018).

Navisão deKristeva, aintertextualidadeimplicaaideia dequeum “[...] significado poético remete a outros, discursivos, de modo a serem legíveis, nesse enunciado poético, vários outros discursos. Cria-se, assim, em volta do significado poético, um espaço textual múltiplo [...]. Chamaremos esse espaço de "intertextual'” (KRISTEVA, 2005, p. 185). Ao complementar essa definição kristeviana, Genette, um pouco diferentemente, afirmou que "[...] o objeto da poética [...] é a transtextualidade, transcendência textual do texto', que, outrora, eu definia, em linhas gerais, como 'tudo que coloca o texto em relação, manifesta ou secreta, com outros textos"'10 (GENETTE, 1982, p. 7, tradução nossa). Assim, Genette assimila a definição de Kristeva, ao que ela chama "intertextualidade", tendo ele

9 Mesmo na língua francesa, essa expressão feita por Gérard Genette é estranha, dada sua (aparentemente) desnecessária redundância - uma vez que a locução adjetiva "do texto" é o exato equivalente semântico do adjetivo "textual". Logo, bastaria ter dito que a transtextualidade é a "transcendência textual”. Porém, como não somos especialistas na obra genettiana, limitar-nos-emos a aceitar a nomenclatura assentada pelo autor.

10 L'objet de la poétique [...] est la transtextualité, ou transcendance textuelle du texte, que je définissais déjà grossièrement par "tout ce qui le met en relation, manifeste ou secrète, avec d'autres textes". 
nomeado uma ideia idêntica como "transtextualidade", a qual se tornaria categoria dotada de cinco subtipos, dos quais a intertextualidade seria o primeiro (tripartido em: “citação”, “plágio”, “alusão”); depois, listam-se "paratextualidade”, "metatextualidade", "hipertextualidade" e "arquitextualidade", quinteto conceitual por cujo intermédio, assim ordenado, tal crítico francês começou a esquadrinhar e explicar os liames textuais. E mais precisamente quanto aos conceitos que aqui usaremos, eis como o próprio Gérard Genette os define:

[...] defino a intertextualidade, em sentido estrito, como uma relação de copresença entre dois ou mais textos, ou seja, eidética e frequentemente, como a efetiva presença de um texto em outro. Sua forma mais explícita e literal é a prática tradicional da citação (aspas, com ou sem referência precisa); forma menos explícita e menos canônica, o plágio [...] é cópia não declarada, mas literal; a forma ainda menos explícita e menos literal é a alusão, enunciado cuja plena compreensão supõe a percepção de sua relação com outro enunciado a que remete esta ou aquela inflexão - não perceptível de outra maneira [...]"11 (GENETTE, 1989, p. 10, tradução nossa).

Neste artigo, com a finalidade de comentarmos os textos bíblicos dos quais se serviu Ruy Belo para a fatura de um poema, que, tão inestimável lhe era (como outros), na época, obteve dupla publicação ${ }^{12}$, lidamos, em específico, com o conceito de "intertextualidade", na visão genettiana, para ligarmos o "Nós os vencidos do catolicismo" a trechos da Bíblia.

\section{"Nós os vencidos do catolicismo": análise, comentário}

Nós os vencidos do catolicismo

11 Quando nos preocupamos em citar este excerto dos Palimpsestos de G. Genette, já não tínhamos a edição francesa em mãos, razão pela qual nos restou consultar a espanhola, de que fizemos uma tradução indireta.

12 Ruy Belo deu duas vezes à estampa o seu "Nós os vencidos do catolicismo": a primeira, no livro Homem de palavra [s], na 12a posição; a segunda, na antologia pessoal País possível (1973), colocado na 9a. posição. 
que não sabemos já donde a luz mana

haurimos o perdido misticismo

nos acordes dos carmina burana

5 Nós que perdemos na luta da fé

não é que no mais fundo não creiamos

mas não lutamos já firmes e a pé

nem nada impomos do que duvidamos

Já nenhum garizim nos chega agora

10 depois de ouvir como a samaritana

que em espírito e verdade é que se adora

Deixem-me ouvir os carmina burana

Nesta vida é que nós acreditamos

e no homem que dizem que criaste

15 se temos o que temos o jogamos

"Meu deus meu deus por que ${ }^{13}$ me abandonaste?"

Dado que analisar poesia mediante comentários é, naturalmente, complexo e requer amplo espaço para sua feitura, não recorreremos a isso, de maneira exaustiva, neste artigo, porque o nosso escopo é uma análise poemática que mostre, em maior ou menor patamar, os meios transtextuais deixados por Ruy Belo nesse seu poema. Sendo assim, miramos as conversas intertextuais feitas à luz da Sagrada Escritura e usadas no "Nós os vencidos do catolicismo".

13 Graças à natureza da ortografia portuguesa praticada em Portugal - a despeito do Acordo Ortográfico de 1990 -, o pronome interrogativo (que, noutros contextos, também é conjunção subordinativa causal e final, ou conjunção coordenativa explicativa) que, no último verso do poema, grafamos "por que" (à maneira da ortografia praticada no Brasil desde, pelo menos, a penúltima Reforma Ortográfica, outrora instaurada pela Lei $\mathrm{N}^{\circ} 5.765$, de 18 de dezembro de 1971), está, no original de Ruy Belo, registrado "porque". Assim, para evitar-se confusão durante a leitura dessa linha poemática, adaptamos aquela palavra às normas ortográficas brasileiras. Demais, no que tange à passagem bíblica de que provém, intertextualmente, a indagação daquele verso final, notório é que, ao se lerem quaisquer traduções brasílicas da Bíblia Sagrada, a palavra que acima mencionamos está, invariavelmente, escrita de maneira bipartida, isto é, "por que", conforme a feição ortográfica que hoje, no Brasil, praticamos. 
Formalmente, o "Nós os vencidos do catolicismo" configura-se em quatro quadras, quer dizer, quatro estrofes de quatro versos (neste texto, decassílabos) cada, cujo esquema rímico é, e nesta ordem, o ABAB (-ismo, -ana, -ismo, -ana), CDCD (-é, -amos, -é, -amos), EBEB (-ora, -ana, -ora, -ana), DFDF (-amos, -aste, -amos, -aste). Há nele rimas pobres ${ }^{14}$, como: "catolicismo"/"misticismo", "creiamos"/"duvidamos", "acreditamos"/ "jogamos", "criaste"/“abandonaste"; também existem rimas ricas ${ }^{15}$ em "mana"/ "burana", "fé"/"pé"16, "agora"/“adora" e "samaritana"/"burana". Evidenciam-se, nas combinações dessas rimas, vínculos semânticos entre palavras que comparecem da primeira à última linha poemática - vejase "catolicismo"/"misticismo", "creiamos"/"duvidamos", "samaritana"/ "burana", "criaste"/“abandonaste". Isso nos põe diante de um percurso descensional do eu lírico, já que é devido à disposição desses vocábulos, no decorrer da leitura do poema, que se veem movimentos que pendem da sublimidade para a humildade.

Todavia, a "humildade", enquanto "[...] qualidade de humilde; virtude caracterizada por consciência das próprias limitações; modéstia, simplicidade; sentimentos de fraqueza e inferioridade com relação a; reverência e respeito para com os superiores; acatamento, deferência, submissão [...]" (HOUAISS; VILLAR; FRANCO, 2009, p. 1.037), é conceito decerto muito apropriado ao "Nós os vencidos do catolicismo". Quando o eu lírico é visto apequenado, isso acontece por motivos que escapam ao controle dele, já que não lhe era possível enfrentar as seduções mundanais, cujas forças inculcam no ânimo da voz poética o sentimento de "[...] que não sabemos já donde a luz mana [...]" (v. 2). E

14 Nome com que se designam, nos Estudos Literários, as rimas entre palavras de mesma classe gramatical.

15 Denominação das rimas que se formam pela relação entre distintas classes gramaticais.

16 Apesar de, morfologicamente, "fé" e "pé" serem substantivos (respectivamente, "abstrato" e "concreto"), pusemo-los entre as chamadas "rimas ricas” porque há, no verso 7, a expressão "a pé”, que, seja em aspecto morfológico, seja em semântico, é uma locução adverbial, do que decorre que não haveria falha em tratar--se "fé" e "pé" como constituintes daquilo que, em Literatura, denomina-se "rima rica". 
essa iluminação, agora desconhecida, tinha por fonte a harmonia entre a díade "catolicismo"/“misticismo”, sem a qual já não poderia haver uma fé subsistente.

Demais, o húmile caráter dessa pessoa poética revela-se ao dizer que "[...] haurimos o perdido misticismo / nos acordes dos carmina burana" (v. 3-4); assim, aquilo que já não se pode obter pela distanciada mística católica, quiçá possa ser conseguido noutro âmbito. Nisso, a expressão “carmina burana”, no supracitado verso, remete à audição de uma peça musical erudita (principalmente profana), condizente ao florilégio denominado, no século XIX, Carmina burana, o “[...] manuscrito medieval contendo poemas e canções (em latim e alto alemão médio), atribuído a poetas vividos entre séculos XI-XIII" (FRANCO, 2009, p. 7). Também sobre tais peças de poesia medieval, associadas ao poema em foco, a crítica literária e jornalista brasileira Manaíra Aires Athayde ${ }^{17}$, ruy-belista que mais informações atuais tem publicado a respeito dos espólios de Ruy Belo, diz-nos, ao comentar $3^{\circ}$ verso:

[... o "perdido misticismo" vai perdendo o espaço para os "acordes dos carmina burana" [...]. Esses textos, de caráter satírico, moral, orgiástico, festivo e idílico, transitam entre o religioso e profano, daí a sutil alusão ao próprio movimento que Ruy Belo criara na passagem da atmosfera em que moveu os seus três primeiros livros para o "clima" implicado em Homem de palavra[s] (ATHAYDE, 2016, p.65-66).

Nesse poema, a intertextualidade começa em "nos acordes dos carmina burana” (v. 4), cujas duas últimas palavras mostram, pela tipologia intertextual chamada referência - consoante a comparatista e crítica literária francesa Tiphaine Samoyault (1968-) -, a qual “[...] não expõe o texto citado, mas a ele remete por um título, nome de

17 Ora rendemos à Profa. Dra. Manaíra Aires Athayde (Stanford University) nossa imensa gratidão por todo o subsídio bibliográfico e dialógico que nos tem concedido, muitíssimo generosamente, para nossos estudos concernentes a Ruy Belo deitarem um pouco mais longe o bastão da crítica da poesia beliana no Brasil. 
autor, personagem ou pela exposição de uma situação específica" (SAMOYAULT, 2008, p. 50).

Intui-se, do anelo do eu lírico por amparar-se “[...] nos acordes dos carmina burana”, que o declínio desse sujeito ascendeu outro grau, porquanto, ao ter optado por uma canção erudita (nos termos etimológicos, ex ruditus, "saído do agreste", "fora do âmbito agrário"; daí "colocado em sublime posição"), fê-lo imperfeitamente, pois que os Carmina burana (ou Canções de Beuern) não são um compósito divino, senão humano. Tal escolha se nota pela temática do Florebat olim, na linha inicial do poema LXIX dos Carmina burana, em cuja 40ª página conservam-se os versos que ora mostramos traduzidos ${ }^{18}$ :

Outrora, florescia o estudo, agora, converte-se em tédio; por muito tempo, vigeu o saber, mas [agora] prevalece o brincar.

5 Já dos meninos a astúcia temporãmente pulula, e os tais, com malevolência, menospreçam a sapiência.

Todavia, em priscos séculos,

10 mal se concedia aos discípulos, conquanto nonagenários, descansar após o estudo.

E, agora, meninos de dez anos, livres do jugo que apartaram,

18 Tradução baseada no texto estabelecido, no ano 1847, pelo filólogo germânico Johann Andreas Schmeller (1785-1852). Cf. Referências Bibliográficas. No original latino: Florebat olim studium, / nunc vertitur in tedium; / iam scire diu viguit, / sed ludere prevaluit. / Iam pueris astutia / contingit ante tempora, / qui per malevolentiam / excludunt sapientiam. / Sed retroactis seculis / vix licuit discipulis / tandem nonagenarium / quiescere post studium. / At nunc decennes pueri / decusso iugo liberi / se nunc magistros iactitant, / ceci cecos precipitant [...]. 


\section{5 jactanciam-se qual mestres}

cegos que a cegos precipitam [...].

Esse trecho das Canções de Beuern nos põe uma leitura do poema "Nós os vencidos do catolicismo" pela possibilidade de que "[...] nos acordes dos carmina burana" (v. 4) e "Deixem-me ouvir os carmina burana" (v. 12) orientem o leitor à visão descaída desse eu lírico para uma vontade que o impele ao mundanismo, que é a “[...] preocupação com este mundo, incluindo inquietação pelas condições sociais. Em outro sentido, é a identificação excessiva com o mundo, isto é, conformar-se a ele [...]" (ERICKSON, 2011, p. 131). Essa é uma concepção adveniente do trecho neotestamentário “[...] não se deixem moldar pelos padrões deste mundo, mas deixem que Deus os transforme pela renovação da mente, para que possam experimentar qual seja a boa, agradável, perfeita vontade de Deus" (BÍBLIA, N.T., Romanos, cap. 12, vers. 2).

Ademais, isso mostra que os dois versos transcritos no parágrafo acima foram feitos numa associação que abarca uma forma intertextual de aspecto referencial-alusivo, já que, além da chamada referência, observa-se um traço de alusão - terceira espécie fatualmente intertextual, segundo a teoria genettiana -, que “[...] pode remeter a um texto anterior sem marcar a heterogeneidade tanto quanto a citação. E é, às vezes, exclusivamente semântica, sem ser intertextual propriamente $\operatorname{dita}^{19}[\ldots]$. Outras vezes, remete mais a uma constelação de textos do que a um texto preciso" (SAMOYAULT, 2008, p. 50). E dada a sua natureza, tal "[...] alusão depende mais do efeito de leitura que as outras práticas intertextuais: tanto pode não ser lida quanto também o ser onde não existe. A percepção

19 É estranho saber deste descompasso com a evidência de que, independentemente de como fazer um texto remeter a outro, basta a mais mínima indicação (que ocorre, no mais das vezes, alusivamente) de uma ideia em outra para perceber que estamos diante de uma irrefragável relação intertextual. Daí Gérard Genette ter dito que isso sempre acontece quanto a “[...] tudo que coloca o texto em relação, manifesta ou secreta, com outros textos” (GENETTE, 1982, p. 7). Logo abaixo disto, que se nomeia por "transtextualidade", situa-se a "intertextualidade", parte da qual se manifesta por meio da "alusão". Logo, a alusão é amiúde intertextual. 
da alusão é subjetiva, e o seu desvendamento raramente é necessário à compreensão do texto [...]" (p. 50).

Discordamos, no entanto, desta última afirmação de Samoyault (2008), já que, se a intelecção dos textos em que haja alusões não dependesse também delas, por qual motivo, então, o autor deles as teria ali colocado? Se existe algo que a Semântica e a Hermenêutica podem nos ensinar, é que todos os elementos que constituem um texto (verbal, não verbal, sincrético) têm fatual importância, seja para compreendê-los, seja para interpretá-los. Por isso, não haveria justificativa para ignorarmos o sintagma nominal "carmina burana" (v.4; 12), ainda mais sabendo que uma alusão, ainda que imperceptível, funciona como um tipo de "suma citacional", porquanto contém, em seu núcleo, uma síntese significativa do texto de que provieram as ideias basilares reordenadas na nova tessitura. Naquilo que ora vimos comentando, a frase alusiva "carmina burana" aponta, a um só tempo, para os homônimos poemas medievais (por citação, explícita) e o Novo Testamento (por alusão ${ }^{20}$, implícita).

Em aspecto etimológico, importa saber que o substantivo "alusão" (do latim allusio, allusionis) e o verbo "aludir" (latim: alludo, alludere) indicam a "ação de brincar, de fazer brincadeira, de gracejar etc.", presente nos morfemas radicais $\{-l u s-\}$ e $\{-l u d-\}$. Portanto, a prática lúdica provinda das alusões é um mecanismo linguístico cujo bom uso em muito acrescenta ao texto no qual aparecem.

Naqueles versos das Canções de Beuern, há traços do tópico do "mundo às avessas" - que tem certa identidade com o "desconcerto do mundo" camoniano -, que "[...] assume diferentes modalidades, cada qual determinada pelas específicas circunstâncias históricas, morais e literárias; [...] o que está na base desse tópico é expressão dum descontentamento [...]" (SPINA, 2009, p. 193). Essas características não propiciam ao Homem afastar-se do mundanismo, porquanto existe, no mundo, uma

20 A “alusão" a que ora nos referimos é aquela que se obtém por meio de um processo interpretativo, cujo sucesso depende de quão vasto seja o repertório literário (inclusive bíblico) de um leitor. Quanto maior esse acervo, menos distante é a percepção dos caracteres alusivos. 
altíssima atração que se impõe a "[...] um fraco humano, / [...] bicho da terra tão pequeno [...]” (CAMÕES, 2009, p. 98). Reparamos, com isso, que o eu lírico do poema beliano está descontente num nível em que o faz supor, convictamente, que não mais vale o esforço de andar com Deus; a despeito disso, a súplica vista na linha final ${ }^{21}$ de "Nós os vencidos do catolicismo" indica, antes, medo e desespero.

Do par rímico "samaritana”/"burana” explicamos o segundo termo. Acerca do outro se diz que, “[...] após conquista de Samaria (721), grande parte da população foi deportada e substituída por colonos assírios [...]. Formou-se no antigo reino do Norte uma população mista, os samaritanos, [...] os quais se puseram monoteístas e aceitaram a lei mosaica [...]” (VAN DEN BORN, 1977, p. 1380-1381). E já desde o “[...] tempo de Cristo, 'samaritano' era invectiva, e judeus não se comunicavam com samaritanos. De outro lado, samaritanos incomodavam peregrinos judeus que iam a Jerusalém [...]” (p. 1381). Tais descobertas de procedência históricoarqueológica nos ajudam a entender por que o eu poético evoca um importante adjetivo gentílico ("samaritana"), "depois de ouvir como a samaritana" (v.10), ligado ao "Deixem-me ouvir os carmina burana" (v.12), porque isso atesta a nítida relação "samaritana”/“burana”. Assim, é o vocábulo "samaritana" (agora substantivado) que situa o leitor frente à nova alusão nesse poema de Ruy Belo.

Quanto ao contexto original em que surge a palavra "samaritana"22, deve-se recorrer ao mais famoso gênero textual do Novo Testamento: a parábola. Ela é definida como “[...] narrativa curta, não raro identificada com o apólogo e a fábula em razão da moral explícita ou implícita que encerra e da estrutura dramática. [...] E, conquanto se possam arrolar uns exemplos profanos, a parábola identifica-se com espírito da Bíblia [...]” (MOISÉS, 2004, p. 337). Ademais, “[...] o Novo Testamento é o contexto

$21 \quad$ Nós a comentaremos mais detalhadamente alguns parágrafos adiante.

22 Nos variados modos com que aparece, na mais recente edição brasileira da Sagrada Escritura, tem-se 12 ocorrências de "samaritano(s)"/"samaritana(s)": 01 no Antigo Testamento e 11 no Novo. Cf. Referências. 
da constituição da parábola como gênero literário. Mesmo que tal modalidade seja mencionada em outros universos, [...] é no Novo Testamento que ela assume feições definidas" (SANT'ANNA, 2010, p. 11).

Mas desse rol parabólico neotestamental há uma dúplice situação bíblica na qual se refere aos habitantes de Samaria: nos textos evangelísticos "O bom samaritano" (BÍBLIA, N.T., Lucas, cap. 10, vers. 25-37) e "Jesus e a mulher samaritana" (BÍBLIA, N.T., João, cap. 4, vers. 1-42). Mencionamos a primeira parábola para mostrar a identidade gentilícia entre o homem nela retratado e a mulher da outra narrativa. Da segunda parábola, faremos citação do que interessar para o leitor averiguar por que o eu lírico recorreu a essa história, para relacionarmos "[...] depois de ouvir como a samaritana / que em espírito e verdade é que se adora [...]" (v. 10-11) a "Deixem-me ouvir os carmina burana" (v. 12), cuja análise findará em "Já nenhum garizim nos chega agora [...]" (v. 9).

Noutro trecho bíblico, narra-se que, acompanhado dos seus discípulos, Jesus Cristo "[...] deixou a Judeia, retirando-se [...] para Galileia. Era-lhe necessário passar pela região da Samaria. Assim, Jesus chegou a uma cidade samaritana [...]. Cansado da viagem, Jesus sentouse junto ao poço. [...] Nisso, veio uma mulher samaritana tirar água [...]" (BÍBLIA, N.T., João, cap. 4, vers. 3-7). Logo, do versículo $7^{\circ}$ ao $22^{\circ}$, Jesus e a samaritana conversam e, no instante em que discorriam sobre o verdadeiro local para adorar ao Deus de Israel - se em Jerusalém, se em Samaria -, o Messias profetiza: "[...] vem a hora, e já chegou, em que os verdadeiros adoradores adorarão ao Pai em espírito e em verdade. Porque são esses que o Pai procura para seus adoradores. Deus é espírito e é necessário que seus adoradores o adorem em espírito e verdade" (BÍBLIA, N.T., João, cap. 4, vers. 23-24). E, antes disso, aquela samaritana afirma: "Agora, sei que o senhor é profeta. Nossos pais adoravam neste monte, mas vocês dizem que Jerusalém é o lugar onde se deve adorar [...]" (BÍBLIA, N.T., João, cap. 4, vers. 19-20). Sabendo dessas amostras, podemos ler as três linhas iniciais da terceira estrofe do poema de R. Belo menos obscuramente: "Já nenhum garizim nos chega agora / depois de ouvir como a samaritana / 
que em espírito e verdade é que se adora [...]” (v.9-11). Assim, vemos que Ruy Belo lançou mão de referência (v. 10) e citação (v. 11).

Agora, para compreender por inteiro essa sequência de versos, discorramos sobre a palavra "garizim" - cujo registro não há nos dicionários de língua portuguesa (por ser um topônimo específico), senão em teológicos -, que se define por: “[...] cume nas montanhas de Efraim [...] a sul da antiga Siquém, na frente do Ebal [...], onde, em tradição samaritana, Josué haveria construído o altar e onde estava o templo dos samaritanos que, em 128 a.C., foi destruído por J. Hircano" (VAN DEN BORN, 1977, p. 620). Mais: “[...] Garizim, no entanto, continuou a ser lugar de orações e sacrifícios para samaritanos, e o é até hoje” (p. 620). O texto "Jesus e a mulher samaritana" (versículos 25-42) diz que a interlocutora de Jesus Cristo acreditou nele e, tendo testemunhado a samaritanos sobre a revelação que tivera, admitiram: “[...] não é mais pelo que você falou que nós cremos, e sim porque nós mesmos ouvimos e sabemos que este é verdadeiramente o Salvador do mundo" (BÍBLIA, N.T., João, cap. 4, vers. 42).

No entanto, aconteceu à voz poética de R. Belo o oposto do que à mulher de Samaria se dera, já que, ao ter declarado que "Já nenhum garizim nos chega agora / depois de ouvir como a samaritana / que em espírito e verdade é que se adora [...]”, sugere que conhece o $4^{\circ}$ capítulo do Evangelho joanino (versículos 23-24), mas no qual já não crê - ainda mais no que diz respeito à revelação acerca do Filho de Deus. Devido à opção do eu lírico, isto é, de já não manter sua fé em Jesus Cristo, o foco creditício dessa voz poética desloca-se das sendas celestes para as terrenas. Isso acontece quando o eu lírico substitui a santidade, simbolizada pelo Monte Garizim, pela mundanidade, figurada nas Canções de Beuern. E disso decorre ser possível lermos "Deixem-me ouvir os carmina burana" pela lente de um espírito humano ansioso por livrar-se do calabouço em que julga ter sido lançado. Esse é, pois, um efeito de sentido que se permite mediante a intertextualidade referencial-alusiva.

Após a explicação samaritana, tratemos da vida. "Nesta vida é que nós acreditamos" (v. 13) nos faz, a partir da segunda palavra que o 
compõe, pensar no que ele significa. Daí que, entre bastantes sentidos, ficamos com alguns que se adéquam ao poema de Ruy Belo: “[...] referese à vida física, que é biológica em sua natureza, ou espiritual, estado de vivo, responsivo e ativo no reino espiritual” (ERICKSON, 2011, p. 206). É, de resto, a chamada "vida na carne", descrita numa epístola paulina, na qual pede que os moradores da Galácia “[...] vivam no Espírito e jamais satisfa [çam] o desejo da carne. Porque a carne luta contra o Espírito, e o Espírito luta contra a carne, porque são opostos entre si para que vocês não façam o que querem [...]” (BÍBLIA, N.T., Gálatas, cap. 5, vers. 1617). E essa carnalidade provinda do "pecado original", que é "[...] efeito do pecado de nossos antepassados, e em particular o de Adão, sobre nós" (ERICKSON, 2011, p. 149), também “[...] pode envolver a corrupção da natureza humana e a culpa” (p. 149). Isso tudo diminui o espírito humano. Em "Nós os vencidos do catolicismo", o eu lírico, imerso numa natureza carnal/caída, ao dizer que "Nesta vida é que nós acreditamos [...]", marca uma posição de confronto direto com outro sentido - um dos mais importantes, aliás - que, na Sagrada Escritura, há para o nome "vida", cujo sentido se dá em uma das identificações que Jesus Cristo revela sobre sua natureza celestial: "[...] Eu sou o caminho, a verdade e a vida [...]" (BÍBLIA, N.T., João, cap. 14, vers. 6). Logicamente, quando Ruy Belo faz o eu lírico, em um verso como aquele, confessar que acredita, unicamente, numa vida física/terreal, ele o faz de maneira a sugerir que está rejeitando a oferta feita pelo Filho de Deus: a da vida eterna.

E depois, em "[...] e no homem que dizem que criaste $[\ldots]$ ” (v. 14), conclui a rejeição o eu lírico quando diz que já não acredita que Deus tenha criado a humanidade. Está claro em "[...] dizem que criaste [...]”, que é nuclear para a interpretação de que essa voz poética não acredita no que "dizem" quanto à origem edênica da humanidade. Uma consequência, para esse eu poético, é que ele anseia pelo "mundo", que é, "[...] nas Escrituras, a terra, o cosmos ou uma força espiritual que se opõe a Deus" (ERICKSON, 2011, p. 131), e jamais pelo "mundo vindouro", identificado com "[...] ordem futura sob o reinado de Cristo [...]" (p. 131), pois, semanticamente, a nobreza relacionada com a livre-escolha 
humana subjaz à possibilidade de leitura segundo a qual o par rímico "criaste" /"abandonaste" nos indique a intenção de Deus para com os seres humanos: criou-os para abandoná-los. Ainda quanto ao verso "[...] e no homem que dizem que criaste”, vê-se um diálogo com o primeiro livro bíblico, ao aludir a esta passagem:

Deus disse:

- Façamos o ser humano à nossa imagem conforme a nossa semelhança. Tenha ele domínio sobre os peixes do mar, sobre as aves dos céus, sobre os animais domésticos, sobre toda a terra e sobre todos os animais que rastejam pela terra.

Assim Deus criou o ser humano à sua imagem, à imagem de Deus criou; homem e mulher os criou (BÍBLIA, A.T., Gênesis, cap. 1, vers. 26-27).

Nesse passo veterotestamentário, relata-se a criação do Homem, e, já que Ruy Belo, no $14^{\circ}$ verso do poema, utiliza a forma verbal "criaste" e o substantivo "homem", são eles suficientes para classificar essa intertextualidade como alusão, já que aqueles dois termos constam na passagem bíblica acima transcrita. Esse fato mostra a tomada de uma das mais comentadas narrativas do Antigo Testamento para, em intertexto, pô-la em xeque, pois o eu lírico que profere seu ceticismo o faz apontando para o trecho veterotestamental, e isso também nos permite compreender por que, no "Nós os vencidos do catolicismo", existem os recursos intertextuais que vimos abordando neste trabalho, pois que é deles que provém - mediante subsídios bíblicos - a matéria para forjar uma voz poética que delibera postar--se de modo quase definitivo contra o Deus judaico-cristão e tudo quanto ele é/representa.

Em "Meu deus meu deus por que me abandonaste?" (v. 16), faz-se intertextualidade pela citação, que é "[...] imediatamente identificável graças ao uso de marcas tipográficas específicas. Aspas e itálico [...] distinguem os fragmentos emprestados" (SAMOYAULT, 2008, p. 49), relacionada a outras passagens da Bíblia Sagrada: 
Deus meu, Deus meu, por que me desamparaste ${ }^{23}$ ? Por que se acham longe de minha salvação as palavras de meu gemido? Deus meu, clamo de dia, e não me respondes; também de noite, porém, eu não tenho sossego (BÍBLIA, A.T., Salmos, cap. 22, vers. 1-2).

A partir do meio-dia, houve trevas sobre toda a terra até as três horas da tarde. Por volta de três horas da tarde, Jesus clamou em alta voz, dizendo:

- Eli, Eli, lemá sabactani? - Isso quer dizer: "Deus meu, Deus meu, por que me desamparaste?” (BÍBLIA, N.T., Mateus, cap. 27, vers. 45-46).

Chegado o meio-dia, houve trevas sobre toda a terra até as três horas da tarde. E, às três horas, Jesus clamou em alta voz: - Eloí, Eloí, lemá sabactani? - Isso quer dizer: "Deus meu, Deus meu, por que me desamparaste?” (BÍBLIA, N.T. Marcos, cap. 15, vers. 33-34).

Nos três excertos bíblicos acima transcritos, percebe-se que os seus próprios autores usaram de intertextualidade por citação - com ênfase quanto ao aproveitamento do Antigo Testamento no Novo -, expressa na literalidade com que o evangelista Mateus da Galileia (século I d.C.) socorreu-se dalguns versículos do salmista, cuja voz, ademais, se confunde com a de Jesus Cristo, pois foi este quem, em agonia na crucificação, proferiu a frase que, cerca de um milênio antes, estivera nos lábios e na pena do rei Davi de Belém (1040-970 a.C.), que, por sete anos, regeu Hebrom, e, ao longo de 33 , Jerusalém. Por fim, quanto ao $22^{\circ}$ capítulo sálmico, a tradição o chama de "Um grito de angústia e um salmo de louvor".

Das duas realidades apresentadas nessa súmula, que dista do texto original (em que, logo, não havia título), Ruy Belo aproveitou, no poema, a parte semântica a qual principia no versículo $1^{\circ}$ e termina

23 Noutras traduções da Sagrada Escritura, está escrito "abandonaste”. Ademais, é óbvio que, se Ruy Belo se tivesse proposto adotar, no lugar daquela forma verbal, outra, um "desamparaste", haveria deslocamento métrico, visto que, em vez do decassílabo que perfaz esse poema, ter-se-ia um verso hendecassílabo no fim desse texto, algo que, mesmo em um poema moderno-contemporâneo, destoaria da proposta abrangida nas dezesseis linhas de que se compõe a quádrupla quadra do "Nós os vencidos do catolicismo". 
no $21^{\mathrm{o}^{24}}$, de maneira que o vínculo intertextual estabelecido entre o último verso beliano e essa frase bíblica encaminha para um sentido que arremata aquela dúvida anunciada apenas duas linhas antes, vertendo-a numa certeza (embora incompleta, visto não se dar por afirmação, senão indagação) sobre Deus: que abandonou/desamparou o eu poético do "Nós os vencidos do catolicismo" - ou, antes, tal é a percepção que a voz lírica tem acerca do destinatário de sua indagação.

E isso aclara, em decorrência dos intertextos com a Bíblia, a predileção de Ruy Belo pelos tipos intertextuais de citação, alusão e referência. Seja no poema recém-comentado, seja noutros de confecção beliana, o poeta queria, nos muitos textos que compôs a respeito da temática judeu-cristã, exprimir as suas ideias quanto à relação divinohumanal. E o fez tendo tomado o quotidiano como arcabouço, ainda mais num Portugal sociopoliticamente turbado como o em que viveu ${ }^{25}$, havendo isso, em algum grau, cooperado para entender a situação lusitana daquele tempo. Apesar disso, o literato nos diz, em um ensaio, quanto à finalidade de um texto poético: "O poema é um objeto, uma coisa do mundo exterior [...]. Passa a ter existência própria [...]” (BELO, 2002, p. 88). Desse modo, por mais embasado na realidade/atualidade que seja, o poemário beliano é um fato artístico - embora dialogue com referenciais objetivos da existência humana.

\section{CONSIDERAÇÕES FINAIS}

É quase certo que Ruy Belo não quis, na arquitetura intertextual soerguida em "Nós os vencidos do catolicismo", mitigar a relevância da tradição bíblica. Com esse poema de Homem de palavra[s], intentou erigir

24 Integralmente, o Salmo 22 tem 31 versículos, cujos primeiros 21 indicam o "grito de angústia", enquanto os demais 10 dizem respeito ao "salmo de louvor".

25 Em específico, sob o Estado Novo, regime político-ditatorial instaurado por Antônio de Oliveira Salazar (1889-1970), sob a égide da Constituição Política da República Portuguesa, de 1933, desde este ano até os 1970. Ruy Belo viveu (desde o seu nascimento), quase integralmente, à sombra do chamado "Salazarismo". 
uma voz poética que atingisse o ideal de acrescentar à estirpe humana um posto metafísico - assim como fez o eu poético camoniano no soneto filosófico-religioso "Verdade, Amor, Razão, Merecimento"-, do qual diz “[...] que não o alcança humano entendimento” (CAMÕES, 2005, p. 199). Por isso é que à mundividência situada nas linhas que daquele poema beliano comentamos resta resignar-se à mais tétrica condição humana: a da imperfeição proveniente do pós-Queda évico-adâmico ${ }^{26}$.

Para realizar as suas produções intertextuais, esse poeta lusitano compulsou páginas da Bíblia Sagrada para demonstrar, o melhor que pudesse, que tal procedimento significa, segundo Ruy Belo, um mero “[...] resultado de leituras profissionais obrigatórias de livros sagrados tomados, no entanto, como profanos" (BELO, 2009, p. 246). Se lemos este passo atentamente, reparamos quão interessante é essa declaração, pois nela vemos que, embora o poeta esteja afirmando o seu estrito compromisso com as suas "[...] leituras profissionais obrigatórias de livros sagrados tomados [...] como profanos", essa obrigatoriedade que se impunha não era igualitariamente distribuída pela consulta a textos de quaisquer religiões, senão, majoritariamente, àqueles ligados ao Judaísmo/Cristianismo.

Então, tenha ocorrido por razões de profissão ou por outras das quais nada sabemos, o fato é que essa opção permite às mencionadas religiões (com destaque à segunda) serem poeticamente representadas de maneira diferente de como, mais de meio milênio antes de Ruy Belo, elas participavam do temário da poesia religiosa portuguesa. Isso porque, desde o século XII até o XIX mais ou menos, confeccionar poemas religiosos consistia, amiúde, na feitura de textos laudatórios a santos católicos (Maria acima dos demais), bem como a Jesus Cristo, a Deus, à cruz do Messias, entre outros temas. Além disso, a importância da escrita de um poema mediante intertextualidade vai além de apenas fazer que um texto se perenize em outro; naquilo que apontamos na relação entre a poesia "Nós os vencidos do catolicismo" e alguns textos do Antigo e Novo Testamento, vimos a elaboração de um eu lírico representativo da

26 Cf. BÍBLIA, A.T., Gênesis, cap. 3, vers. 1-24. 
condição humana no mundo, a qual, invariavelmente, é repleta de uma realidade na qual angústia e desamparo interagem numa lamentatória senda vitalícia.

QUOTATION, ALLUSION, REFERENCE: INTERTEXTUAL PROCEDURES IN THE POEM “Nós OS VENCIDOS DO CATOLICISMO", BY RUY BELO

\section{Abstract}

Ruy de Moura Ribeiro Belo (1933-1978), an important writer of contemporary Portuguese literature, produced dozens of lyric poems related, in different degrees, to the Judeo-Christian theme, having taken the Holy Bible as the primary source of intertextual procedures used by him. We focused on his book Homem de palavra[s] (1970), in which the poem "Nós os vencidos do catolicismo" shows some intertextuality techniques most used by Ruy Belo throughout his lyrical work: quotation, allusion and reference. For knowledge and analysis of them in that poetic text, we will use the definitions provided by the French literary critics Julia Kristeva (1941-), Gérard Genette (1930-2018) and Tiphaine Samoyault (1968-).

KeYwords: Ruy Belo. Nós os vencidos do catolicismo. Intertextuality.

CitA, ALUSIÓN, REFERENCIA: PROCEDIMIENTOS INTERTEXTUALES EN EL POEMA "Nós OS VENCIDOS DO CATOLICISMO", DE RUY Belo

\section{RESUMEN}

Ruy de Moura Ribeiro Belo (1933-1978), importante escritor de la literatura portuguesa contemporánea, produjo decenas de poemas líricos relacionados, en diferentes grados, con la temática judeocristiana, habiendo tomado la Santa Biblia como fuente primaria de los procedimientos intertextuales utilizados por él. Nos centramos en su libro Homem de palavra[s] (1970), en que el poema "Nós os vencidos do catolicismo" muestra algunas de las técnicas de intertextualidad más utilizadas por Ruy Belo a lo largo de su obra lírica: cita, alusión y referencia. Para el conocimiento y análisis de ellos en ese texto poético, utilizaremos 
las definiciones proporcionadas por los críticos literarios franceses Julia Kristeva (1941-), Gérard Genette (1930-2018) y Tiphaine Samoyault (1968-).

Palabras Clave: Ruy Belo. Nós os vencidos do catolicismo. Intertextualidad.

\section{REFERÊNCIAS}

ATHAYDE, Manaíra Aires. Do espólio ao processo de criação. In: ATHAYDE, Manaíra Aires. Ruy Belo e o Modernismo brasileiro: poesia, espólio. Tese (Doutorado em Materialidades da Literatura) - Faculdade de Letras da Universidade de Coimbra, Coimbra, 2016.

BELO, Ruy. Aquele grande rio Eufrates. In: BELO, Ruy. Todos os poemas. Lisboa: Assírio \& Alvim, 2009. p. 9-132.

BELO, Ruy. Homem de palavra[s]. In: BELO, Ruy. Todos os poemas. Lisboa: Assírio \& Alvim, 2009. p. 241-364.

BÍBLIA SAGRADA (Nova Almeida Atualizada). Tradução de João Ferreira de Almeida.

Barueri: Sociedade Bíblica do Brasil, 2017. 1388 p.

CAMÕES, Luís Vaz de. Verdade, Amor, Razão, Merecimento. In: CAMÕES, Luís Vaz de. Rimas. Texto estabelecido e prefaciado por Álvaro J. da Costa Pimpão. Coimbra: Almedina, 2005. p. 199.

CAMÕES, Luís Vaz de. Os lusíadas. Edição organizada por Manuel Paulo Ramos. Porto: Porto, 2009. 642 p.

CÂNDIDO, Antônio. O estudo analítico do poema. São Paulo: Humanitas, 2006, $164 \mathrm{p}$.

CORDEIRO, Gonçalo Vítor Plácido. Velha aliança: da sensibilidade bíblica em alguma poesia portuguesa do final do século XX. 2011. 326 f. Tese (Doutoramento em Estudos Literários - Literatura Comparada) - Faculdade de Letras da Universidade de Lisboa, Lisboa, 2011.

ERICKSON, Millard J. Dicionário popular de teologia. Tradução Emirson Justino. São Paulo: Mundo Cristão, 2011.214 p. 
FRANCO, João José de Melo (org.). Apresentação. In: FRANCO, João José de Melo. Carmina burana - Canções de Beuern: poemas latinos medievais (séculos XI, XII e XIII). Tradução, apresentação e notas de João José de Melo Franco. Rio de Janeiro: Íbis Libris, 2009. 136 p.

FRYE, Herman Northrop. Verticais de Adão. In: FRYE, Herman Northrop. A imaginação educada. Tradução Adriel Teixeira, Bruno Geraidine e Cristiano Gomes. Campinas: Vide Editorial, 2017. p. 93-112.

GENETTE, Gérard. Cinq types de transtextualité, dont l'hypertextualité. In: GENETTE, Gérard. Palimpsestes: la littérature au second degré. Paris: Seuil, 1982. p. 7-14.

GENETTE, Gérard. Palimpsestos: la literatura en segundo grado. Traducción Celia

Fernández Prieto. Madrid: Taurus, 1989.519 p.

HAMBURGER, Käte. O gênero lírico. In: HAMBURGER, Käte. A lógica da criação literária. Tradução Margot P. Malnic. São Paulo: Perspectiva, 1975. p. 167-209.

HOUAISS, Antônio; VILLAR, Mauro de Salles; FRANCO, Francisco Manoel de Mello. Dicionário Houaiss da língua portuguesa. Rio de Janeiro: Objetiva, 2009. 1986 p.

KRISTEVA, Julia. Introdução à semanálise. Tradução Lúcia Helena França Ferraz. São Paulo: Perspectiva, 2005. 212 p.

LIMA, Augusto César Pires de. A poesia religiosa na literatura portuguesa. Porto: Domingos Barreira, 1942. $176 \mathrm{p}$.

RÉGIO, José; SERPA, Alberto de. Na mão de Deus: antologia da poesia religiosa portuguesa. Lisboa: Portugália, 1958. 384 p.

RUBIM, Gustavo. Singular ínfimo. Inimigo Rumor, n.15, p. 87-91, jul./dez. 2003. MOISÉS, Massaud. Dicionário de termos literários. São Paulo: Cultrix, 2004. 520 p. SAMOYAULT, Tiphaine. A intertextualidade. Tradução Sandra Nitrini. São Paulo: Aderaldo e Rothschild, 2008. 158 p.

SANT’ANNA, Marco Antônio Domingues. Introdução. In: SANT'ANNA, Marco Antônio Domingues. O gênero da parábola. São Paulo: Unesp, 2010. p. 11-14. 
SCHMELLER, Johann Andreas (org.). Florebat olimstudium. In: SCHMELLER, Johann Andreas (org.). Carmina burana: lieder und gedichte einer handscrift des XIII jahrhunderts aus Benedictbeuern. Breslau: Wilhelm Koebner, 1883. p. 40.

SILVA, José Maria da Costa. Ensaio biográfico-crítico sobre os melhores poetas portugueses. Lisboa: Imprensa Silviana, 1854. 330 p. v. 7.

SPINA, Segismundo. O formalismo estético trovadoresco. São Paulo: Ateliê, 2009. 232p.

VAN DEN BORN, A. (org.). Dicionário enciclopédico da Bíblia. Tradução Frederico Stein. Petrópolis: Vozes, 1977. 1589 p.

Submetido em 30 de setembro de 2020

Aceito em 09 de dezembro de 2020

Publicado em 14 de fevereiro de 2021 